\author{
Mustafa B. Erten, ${ }^{1}$ Danny D. Reible, ${ }^{2}$ Robert B. Gilbert, ${ }^{3}$ \\ and Chadi S. El Mohtar ${ }^{4}$
}

\title{
The Performance of Organophilic Clay on Nonaqueous Phase Liquid Contaminated Sediments Under Anisotropic Consolidation
}

\begin{abstract}
REFERENCE: Erten, Mustafa B., Reible, Danny D., Gilbert, Robert B., and El Mohtar, Chadi S., "The Performance of Organophilic Clay on Nonaqueous Phase Liquid Contaminated Sediments Under Anisotropic Consolidation," Contaminated Sediments: Restoration of Aquatic Environment on May 23-25, 2012 in Montreal, Quebec, Canada; STP 1554, C. N. Mulligan and S. S. Li, Editors, pp. 32-44, doi:10.1520/STP104214, ASTM International, West Conshohocken, PA 2012.
\end{abstract}

\begin{abstract}
Disturbance of a nonaqueous phase liquid (NAPL) contaminated sediment; for example the loading-induced consolidation after placement of a sediment cap, may result in the release of the NAPL. Organophilic clays are reported as effective media in adsorbing NAPLs and organic contaminants. Consolidation tests were performed to evaluate the effectiveness of placement of an organophilic clay layer to capture any such displaced NAPL. NAPL contaminated specimens were tested in a modified triaxial setup under anisotropic loading conditions. Kaolinite was used to represent the sediment solid phase and Soltrol 130 (a type of mineral oil) was used to represent the NAPL. The tests with no organophilic clay showed that higher NAPL saturation resulted in a stiffer soil matrix, which reduced NAPL expulsion. The more organophilic clay was used, the less NAPL release was observed. For the conditions of this study, no NAPL breakthrough was
\end{abstract}

Manuscript received July 16, 2011; accepted for publication February 28, 2012; published online October 23, 2012.

'Gruduate Research Assistant, Dept. of Civil, Architectural, and Environmental Engineering, Univ. of Texas at Austin, Austin, TX 78712-0273 (Corresponding author), e-mail: mberten@mail.utexas.edu

${ }^{2}$ Bettie Margaret Smith Chair of Environmental Health Engineering, Dept. of Civil, Architectural, and Environmental Engineering, Univ. of Texas at Austin, Austin, TX 78712-0273.

${ }^{3}$ Brunswick-Abernathy Regents Professor, Dept. of Civil, Architectural, and Environmental Engineering, Univ. of Texas at Austin, Austin, TX 78712-0273.

${ }^{4}$ Assistant Professor, Dept. of Civil, Architectural, and Environmental Engineering, Univ. of Texas at Austin, Austin, TX 78712-0273. Copyright (C) 2012 by ASTM International, 100 Barr Harbor Drive, PO Box C700, West Conshohocken, PA
19428-2959. 
observed, when the initial NAPL saturation of kaolinite was $28 \%$ with a layer of organophilic clay on top. The adsorption capacity of organophilic clay with this oil was approximated as $1.2 \mathrm{ml}(0.93 \mathrm{~g})$ per $1 \mathrm{~g}$ of organophilic clay solids. Organophilic clay reached its full adsorption capacity independent of the volume and rate of $\mathrm{NA} \bar{P} L$ expulsion during consolidation. These data provide guidance to estimate the quantity of organophilic clay needed for site-specific applications.

KEYWORDS: organophilic, NAPL, contamination, sediment

\section{Introduction}

Nonaqueous phase liquids (NAPLs) are hazardous organic liquids which are immiscible in water. NAPLs have accumulated in some sediments as a result of past industrial activities. Although this NAPL is typically heavily weathered with few remaining mobile components, disturbance of the sediments can lead to release of the NAPL. As a result, in situ management of the NAPL contaminated sediments in rivers, lakes, and ponds through capping is often desirable. Sediment capping involves placement of a clean sediment or sand layer over the contaminated sediments. However, this may also lead to disturbance due to substantial consolidation of the sediments and displacement of previously contained NAPL. This displacement may be of particular concern when an inert nonsorbing layer of material is placed on top of the contaminated layer $[1,2]$. An inert cap material may not be very effective because NAPL breakthrough into the clean water may occur as a result of the consolidation of the underlying sediment.

In cases where NAPL migration is a concern, the use of an amended layer that may work to actively control the migrating contaminant phase, i.c., active capping, may be warranted. The use of NAPL sorbing material such as organophilic clay may be an effective means of controlling NAPL migration. Organophilic clays are manufactured by exchanging the inorganic cations (sodium and calcium) in the clay structure with a quaternary amine containing a long chain organic group [3]. This process results in a hydrophobic soil structure that can adsorb dissolved and separate phase organic contaminants.

Laboratory tests on organophilic clays provide data for its ability to adsorb oil. Alther [4] reported that in a batch test, organophilic clay adsorbed oil up to $70 \%$ of its own weight. Moazed [3] performed batch tests with organophilic clay in five different oil and/or water mixture media. The weight of adsorbed oil was between $30 \%$ and $70 \%$ of the initial weight of the organophilic clay.

Paul et al. [5] and Lo and Yang [6] reported that when organophilic clay adsorbed organic materials, it would swell. This swelling results in a decrease in the hydraulic conductivity of the organophilic clay. This swelling may be desired when organophilic clays are used in geosynthetic liners where contaminants need to be sealed off from the surrounding environment. However in 
river beds, when the hydraulic conductivity of the cap material drops, it may restrict the natural upflow of water.

The sorption capacity of organophilic clay is usually measured by batch studies. Batch tests represent the most ideal conditions for the NAPL adsorption and measure the maximum sorption capacity of the organophilic clay. This may not represent the actual condition of the organophilic clay when placed on the sediment in river beds, especially if the consolidation of the sediment triggers NAPL migration; the adsorption capacity of organophilic clay may be reduced drastically as a result of the dynamic consolidation process.

Measuring the adsorption capacity of organophilic clay integrated into a consolidation test can better mimic field conditions and give a more accurate insight on the expected organophilic clay performance. Steward [7] used a modified triaxial setup to perform consolidation tests on NAPL contaminated field sediments. Moretti [8] used the same setup to investigate the performance of organophilic clay, which was placed on top of the specimens. Erten et al. [9] developed a laboratory specimen preparation procedure and performed consolidation tests on reconstituted sediment samples and modified a triaxial setup to adapt for consolidation testing under very low stresses.

In this study, consolidation tests were performed on reconstituted sediment samples with a layer of organophilic clay (CETCO PM $199^{\mathrm{TM}}$ ) placed on top of them. The consolidation tests were performed in a modified triaxial frame and the loads were determined to represent different cap heights on top of the organophilic clay layer. The effluents were collected in bladder accumulators. NAPL and water contents of the specimens were determined by a hexane extraction procedure and moisture content tests.

\section{Test Apparatus}

The triaxial testing equipment and procedure described in Erten et al. [9] was used for the tests in this study. The schematic of the test system is shown in Fig. 1. Bladder accumulators were added to the top and the bottom drainage lines to collect the effluent without contaminating the pressure panel while allowing for volume change measurements. An air piston was attached at the top of the triaxial setup to apply the vertical load needed to achieve $\mathrm{K}_{0}$ consolidation. The precision of the air piston was $0.44 \mathrm{~N}$. A load cell was attached between the air piston and the triaxial cell. A differential pressure transducer was attached to the bottom of the cell and to the bottom of the specimen for direct measurements of the lateral effective stress. Low pressures on the specimen and the cell could be applied accurately using appropriate pressure regulators mounted on the pressure panel. Neoprene membranes were used instead of regular latex membranes due to their higher resistance to NAPL. Vertical deformations were measured by a dial gage at the top of the triaxial cell. 


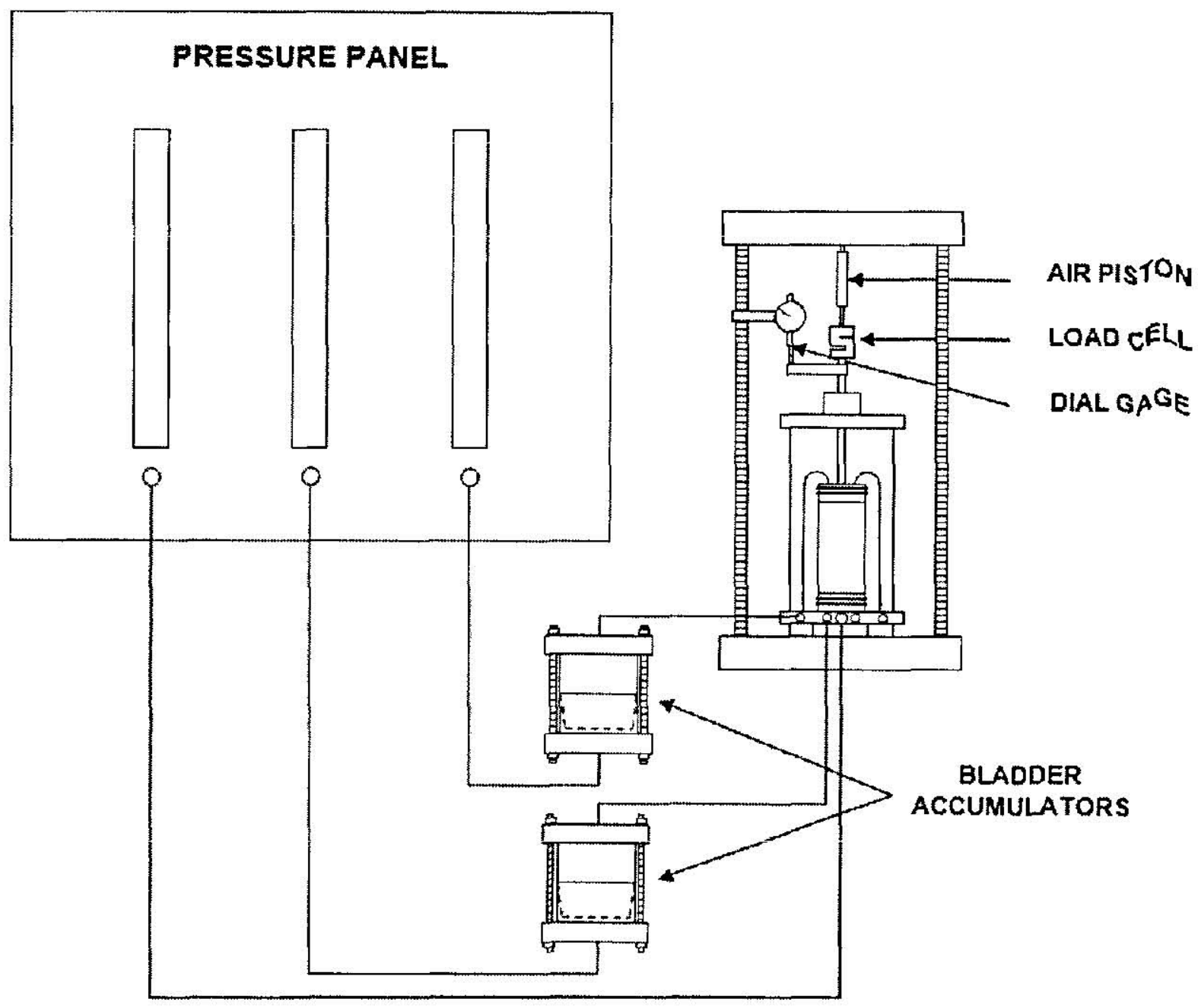

FIG. 1-Schematic of final apparatus.

\section{Materials}

The organophilic clay used in all tests was PM199 ${ }^{\mathrm{TM}}$, which was manufac. tured by CETCO (Hoffman Estates, IL). Pure Georgia kaolinite was used to represent the sediment due to its fine pore structure and well-known properties [9]. Previous studies reported that the specific surface area of pure kaolinite is around $20 \mathrm{~m}^{2} / \mathrm{g}$, while the cation exchange capacity is around $3 \mathrm{meq} / 100 \mathrm{~g}$ [10-12]. The liquid limit and plasticity index of the kaolinite were measured as $58 \%$ and $25 \%$ respectively. The kaolinite had a mean particle size of $0.7 \mu \mathrm{m}$.

Soltrol 130 Isoparaffin solvent was mixed with kaolinite to represent the NAPL phase in sediments. Soltrol 130 is similar to a middle distillate such as diesel or kerosene. In addition, Soltrol 130 is a low viscosity mineral oil, which encourages NAPL mitigation. Because Soltrol 130 is transparent and hard to differentiate from water, it was dyed with Sudan IV, which is a fat soluble, $r d$. colored dye. In all specimens, de-aired tap water was used as the water in the pore fluid. 


\section{Procedure}

Consolidation stresses were calculated for a hypothetical case in which the sediment specimen was located $1.1 \mathrm{~m}$ below the mudline and $3.0 \mathrm{~m}$ of water was overlying the sediment (Fig. 2). Consolidation tests were performed in five stages to represent the sediment's initial stress condition and varying cap heights of 0.5 $\mathrm{m}, 0.9 \mathrm{~m}, 1.8 \mathrm{~m}$, and $3.0 \mathrm{~m}$. It should be noted that the maximum cap height simulated in these tests was $3.0 \mathrm{~m}$, which is a greater load than what would normally be expected [13]. Therefore, NAPL breakthrough may be lower than the values reported in this study in a field application, depending on the cap thickness.

Table 1 shows the calculated vertical effective stress values at various cap heights. The unit weight of cap material and the sediment were approximated as $20 \mathrm{kN} / \mathrm{m}^{3}$ and $16 \mathrm{kN} / \mathrm{m}^{3}$, respectively. The vertical effective stresses were calculated for the geometric condition given in Fig. 2. The different cap heights on the sediment were simulated as a change in the vertical effective stress on the triaxial specimen. El-Sherbiny [15] consolidated Georgia kaolinite in a tub filled with water and measured the moisture content profile of the kaolinite sediment after consolidation under its own weight. On the basis of the findings of El-Sherbiny's [15] study, the initial void ratio of sedimented kaolinite for the stress condition given was 2.06 . Therefore all samples in this study were mixed to this initial void ratio.

The diameter and the height of the specimens were $5.08 \mathrm{~cm}$ and $10.16 \mathrm{~cm}$, respectively. The specimens were consolidated under anisotropic conditions. In a previous study, it was found that the lateral earth pressure coefficient $\left(\mathrm{K}_{0}\right)$ value of this soil was between 0.6 and 0.7 [9]. A $\mathrm{K}_{0}$ value of 0.7 was used in all tests. Sediment specimens were prepared by hand mixing in a bowl. All specimens were prepared at an initial NAPL saturation of $70 \%$ and water saturation of $30 \%$; for water saturations higher than $30 \%$, the sediment sample was not stable and water pushed NAPL out of the pores. The NAPL content of

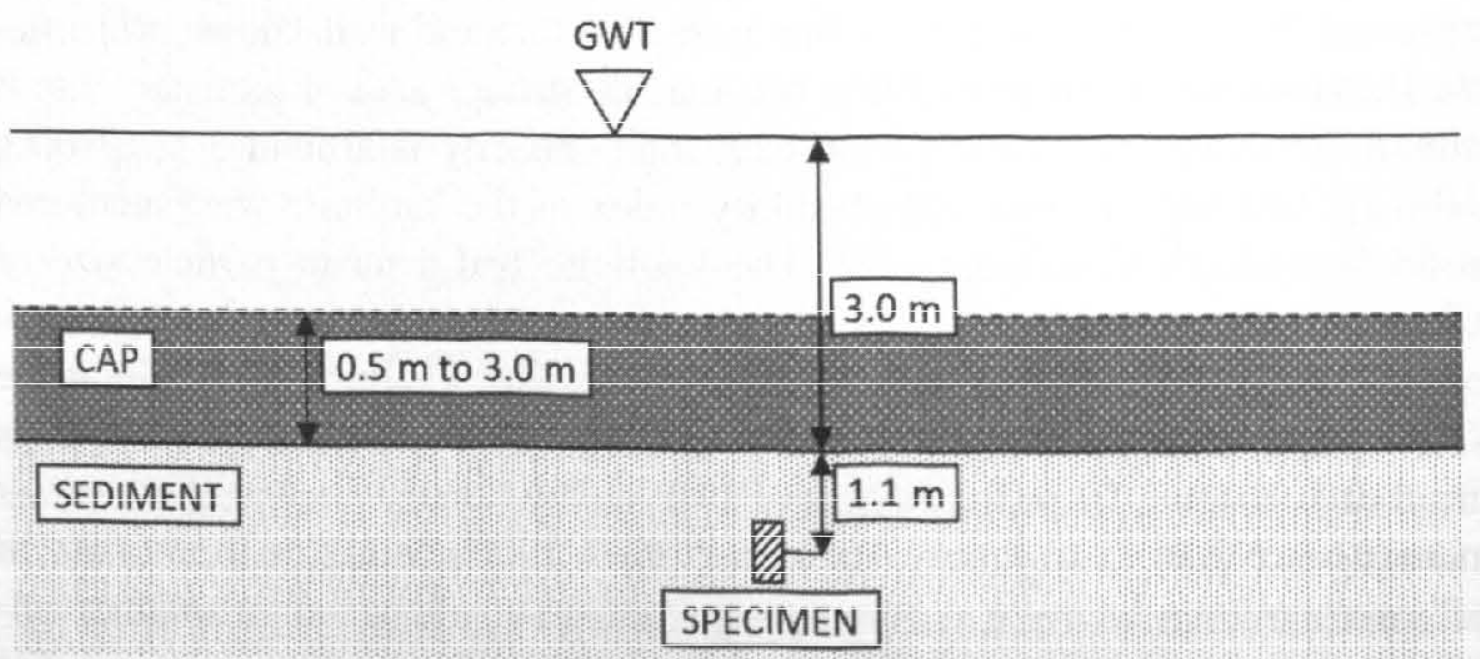

FIG. 2-Location of the hypothetical test specimen. 
TABLE 1-Vertical effective stresses at various consolidation stages [14].

\begin{tabular}{lcc}
\hline Consolidation Stage & Field Condition & Vertical Effective Stress (kPa) \\
\hline I & in situ & 6.3 \\
II & 0.5 m cap & 11.2 \\
III & 0.9 m cap & 16.0 \\
IV & 1.8 m cap & 25.7 \\
V & 3.0 m cap & 38.7 \\
\hline
\end{tabular}

the specimens was reduced to the desired initial NAPL saturation by flushing water through the specimen from the top to the bottom. The displaced fluid from the bottom was always NAPL or NAPL-water mixture, meaning that the NAPL content of specimens could be reduced to the desired value successfully using this procedure.

The membrane was stretched around a split mold (similar to the one used for preparing sand triaxial specimens) and the sediment mixture was placed into the membrane in several lifts. After each lift, the soil in the membrane was slightly tapped for compaction. All the lines, porous stones, and filter papers were water saturated. In another study, breakthrough pressure of NAPL into the water saturated system was found to be negligible [9]. For tests with the organophilic clay, the amount of organophilic clay was varied from $2500 \mathrm{~g} / \mathrm{m}^{2}$ to $10400 \mathrm{~g} / \mathrm{m}^{2}$. The organophilic clay was submerged in water in a beaker and kept overnight to achieve full saturation. Then, the free water in the beaker was removed and a layer of water-saturated organophilic clay was spread over the sediment using a small spatula.

Hexane extraction [16] and moisture content tests [17] were used to obtain the NAPL distribution along the height of the specimen after the consolidation. A picture of the specimen after a consolidation test is given in Fig. 3. After each consolidation test, the kaolinite portion of the specimen was cut into four horizontal slices. From each slice two samples were taken for the hexane extraction procedure and the moisture content test. The organophilic clay was mixed thoroughly to obtain a homogenous mix and two samples were taken for the hexane extraction procedure and one sample was taken for the moisture content measurement. In reporting the results, the NAPL and water content of the two organophilic clay samples were averaged. Control tests showed that almost $100 \%$ of Soltrol 130 vaporized in $105^{\circ} \mathrm{C}$ after $24 \mathrm{~h}$. Therefore moisture content tests were used to estimate the total fluid content of a slice. The hexane extraction procedure was used to obtain the amount of NAPL in that slice; the water content of the slice was calculated by subtracting the NAPL content from the total fluid content.

The amount of NAPL trapped in the specimen was calculated by measuring the amount of NAPL collected in the bladder accumulators and subtracting this amount from the initial NAPL amount in the specimen. These 


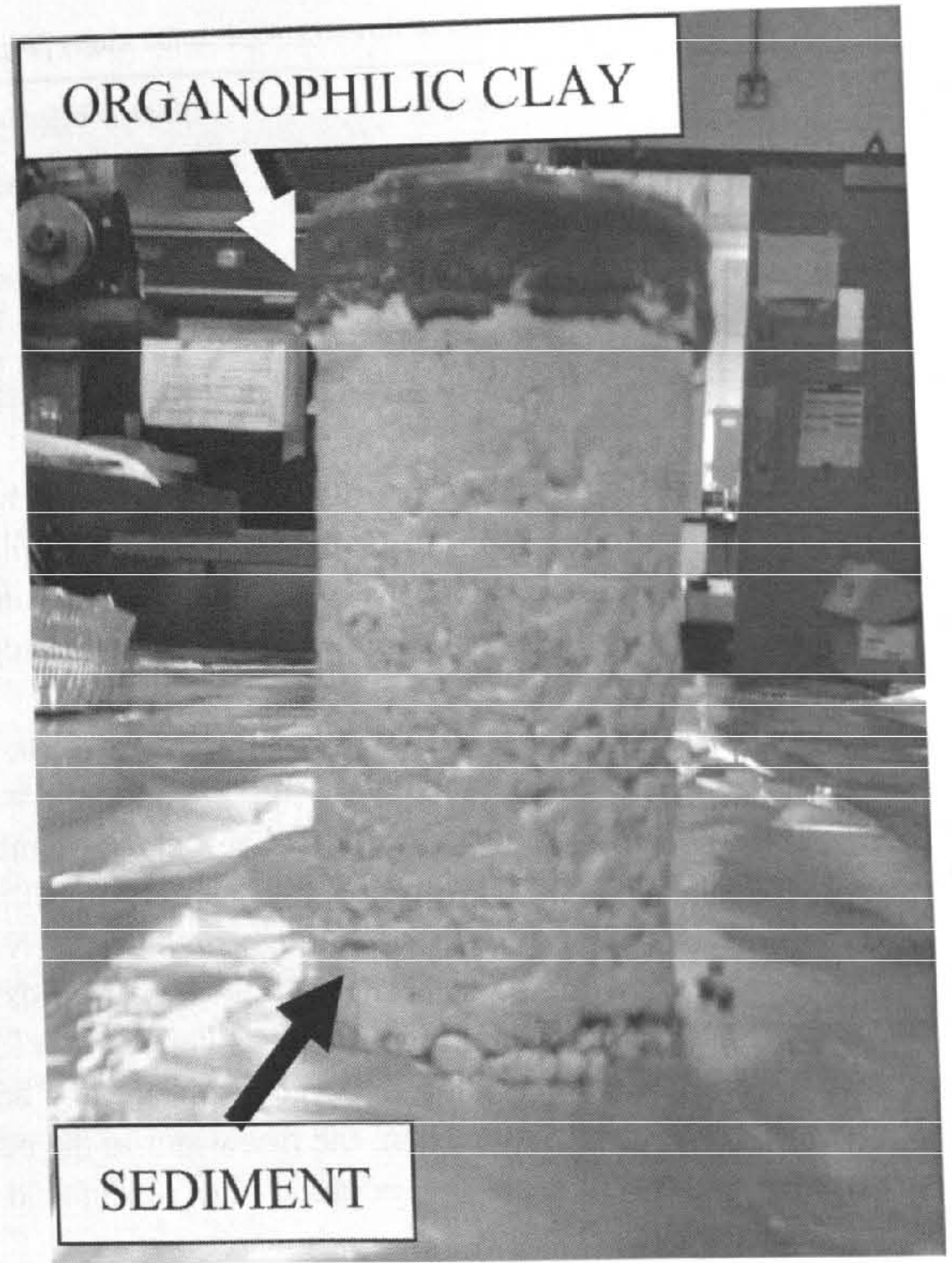

FIG. 3-Sediment specimen after the consolidation.

calculations are shown in Table 2 under the column titled "Consolidation Data." For verification of the amount of NAPL in the specimen, this amount was compared with the amount calculated using the hexane extraction procedure. The hexane extraction procedure measured consistently lower NAPL amounts (Table 2), with differences varying between $5 \%$ and $16 \%$ of the actual volume. This difference was attributed to the NAPL losses during the

TABLE 2 - Comparison of consolidation tests at different initial NAPL saturations.

\begin{tabular}{ccc}
\hline & \multicolumn{2}{c}{ Volume of NAPL in the Specimen (mi) } \\
\cline { 2 - 3 } $\begin{array}{c}\text { Initial Saturation of NAPL } \\
\text { in Kaolinite (\%) }\end{array}$ & Consolidation Data & Hexane Extraction \\
\hline 28 & 33 & 28 \\
49 & 38 & 32 \\
70 & 57 & 54 \\
\hline
\end{tabular}


specimen preparation and Soxhlet extraction while performing the hexane extraction procedure, and it is accounted for in analyzing the test data.

\section{Results}

\section{Control Tests}

Control tests without organophilic clay were performed on sediment samples at various initial NAPL saturations from $15 \%$ to $100 \%$. Figure 4 shows the weight of expelled NAPL normalized to the weight of kaolinite solids for each specimen. The previous study [9] showed that for this soil and testing conditions, when the NAPL saturation was below $\sim 18 \%$, NAPL was no longer mobilized and trapped in the soil pores. Therefore in Fig. 4, no NAPL breakthrough was observed below $20 \%$ of initial NAPL saturation. The final vertical effective stress in all tests was $38.7 \mathrm{kPa}$. The expelled NAPL amount at the end of each test was determined by measuring the amount collected in the bladder accumulators. At higher NAPL contents, more NAPL tends to be displaced as a result of consolidation (Fig. 4). This trend can be observed up to around $50 \%$ of initial NAPL saturation. On the other hand, when clay particles are exposed to a non-polar fluid, Soltrol 130 in this study, diffuse double layers around the clay particles shrink and the clay particles form a more flocculated structure [18]. This structure results in a stiffer soil matrix so that reduces the volume of expelled fiuid. The effect of this phenomenon can be observed on Fig. 4 when the initial NAPL saturation is higher than $50 \%$.

Figure 5 shows the maximum flow rates of consolidation for three tests after $1 \mathrm{~min}, 10 \mathrm{~min}, 100 \mathrm{~min}$, and $1000 \mathrm{~min}$. The rate of consolidation values ranged between $1 \times 10^{-2} \mathrm{ml} / \mathrm{s}$ and $7 \times 10^{-2} \mathrm{ml} / \mathrm{s}$ for these NAPL saturations,

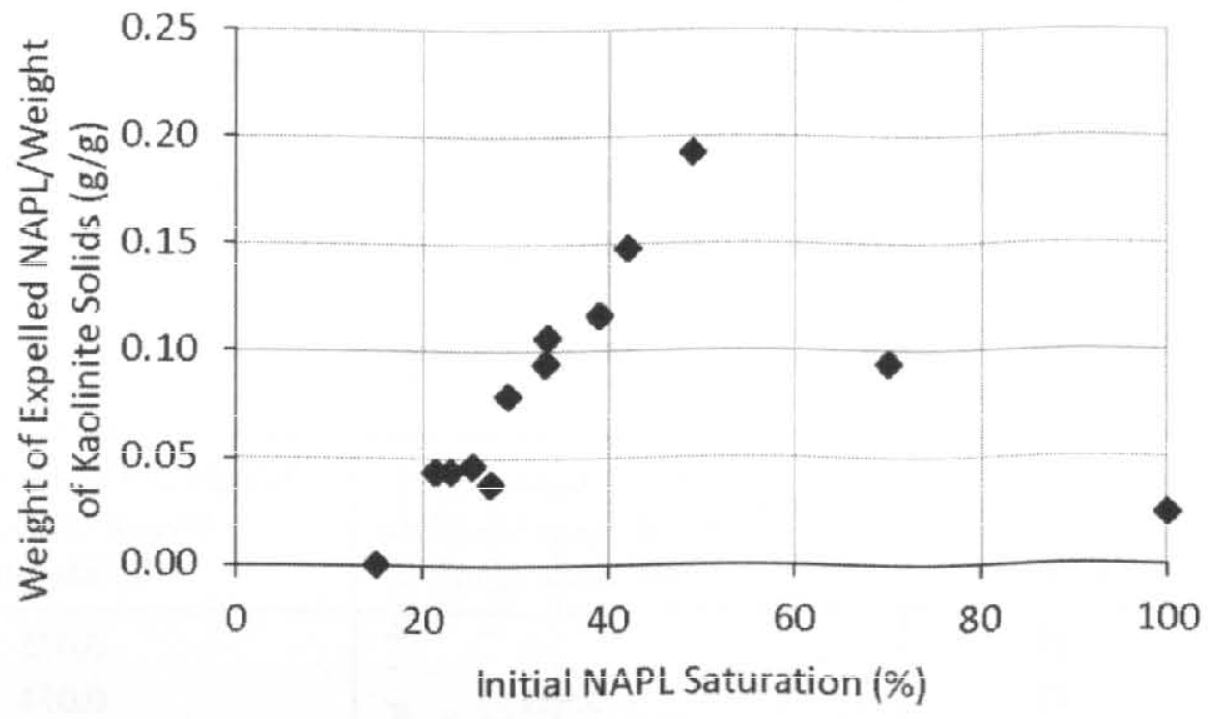

FIG. 4-Weight of expelled NAPL per weight of sediment solids at various initial NAPL saturations. 


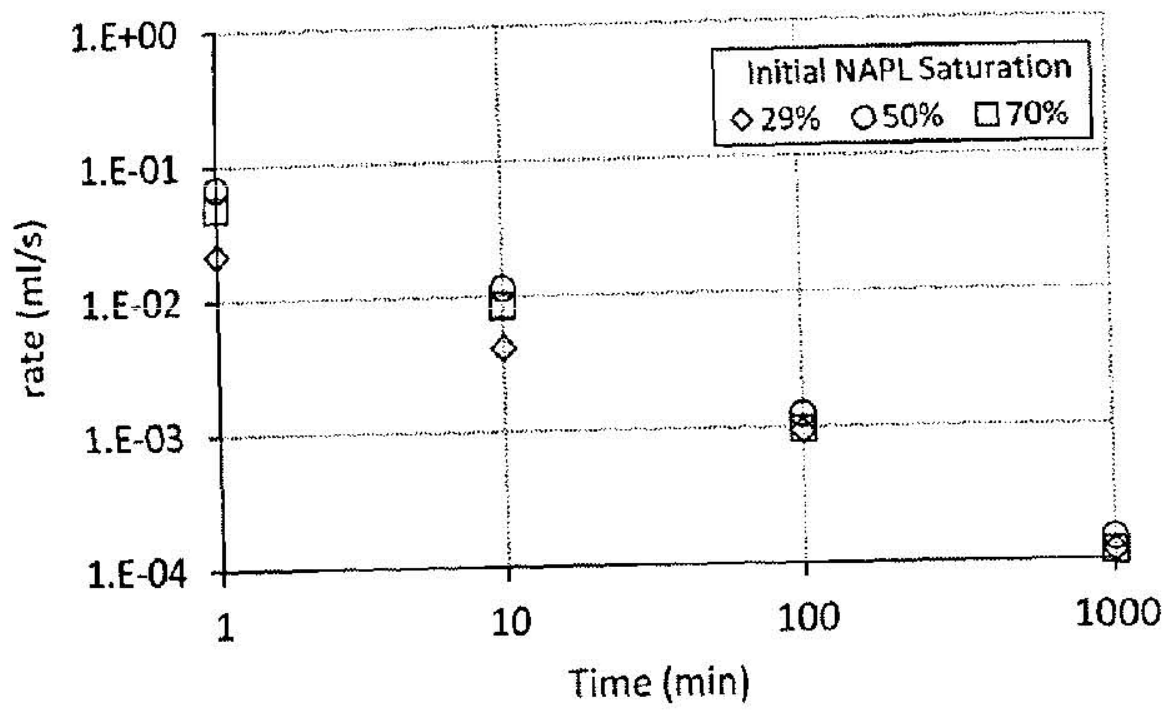

FIG. 5-Rate of flow after $1 \mathrm{~min}, 10 \mathrm{~min}, 100 \mathrm{~min}$, and $1000 \mathrm{~min}$.

decreasing with time due to consolidation. For the tests with $50 \%$ and $70 \%$ of initial NAPL saturations, only NAPL expulsion was observed during consolidation. Maximum flow rates were observed when the initial NAPL content was $50 \%$, due to the relatively high water saturation, which promoted faster NAPL expulsion compared with the specimen with $70 \%$ initial NAPL saturation.

\section{Tests with Organophilic Clay}

Various amounts of water saturated organophilic clay were placed as a NAPL containment layer at the top of the triaxial specimens. The specimens were consolidated under double drainage condition. Three tests performed at an initial NAPL saturation of about $30 \%$ show that when more organophilic clay is used, less NAPL is expelled (Table 3). At an initial NAPL saturation of $28 \%$ with $10400 \mathrm{~g} / \mathrm{m}^{2}$ of organophilic clay, no NAPL breakthrough was observed. For context, in terms of the rate of adsorption the maximum flow rate from consolidation was about $2 \times 10^{-2} \mathrm{ml} / \mathrm{s}$. These results show that when enough organophilic clay is used, NAPL release can be stopped.

Table 4 shows the NAPL distribution before and after the consolidation for six tests, without and with an organophilic clay layer on the top. Because

TABLE 3-NAPL expulsion when different amount of organophilic clay was used at similar initial NAPL saturation.

\begin{tabular}{cccc}
\hline Test & $\begin{array}{c}\text { Initial Saturation of NAPL } \\
\text { in Kaolinite (\%) }\end{array}$ & $\begin{array}{c}\text { Mass of Organophilic } \\
\text { Clay Solids per Unit Area } \\
\text { of Kaolinite }\left(\mathrm{g} / \mathrm{m}^{2}\right)\end{array}$ & $\begin{array}{c}\text { Weight of Expelled NAPL per } \\
\text { Weight of Kaolinite } \\
\text { Solids }(\mathrm{g} / \mathrm{g})\end{array}$ \\
\hline 1 & 29 & 0 & 0.075 \\
2 & 27 & 2500 & 0.074 \\
3 & 28 & 4100 & 0.016 \\
4 & 28 & 10400 & 0.000 \\
\hline
\end{tabular}


TABLE 4-NAPL distribution (\%) in specimens before and after consolidation under $39 \mathrm{kPa}$ added stress.

\begin{tabular}{|c|c|c|c|c|c|c|c|c|}
\hline \multirow{2}{*}{$\begin{array}{l}\text { Weight of } \\
\text { Kaolinite } \\
\text { Solids (g) }\end{array}$} & \multirow{2}{*}{$\begin{array}{l}\text { Initial Amount } \\
\text { of NAPL in } \\
\text { Kaolinite }(\mathrm{ml})\end{array}$} & \multirow{2}{*}{$\begin{array}{l}\text { Initial Saturation } \\
\text { of NAPL in } \\
\text { Kaolinite }(\%)\end{array}$} & \multirow{2}{*}{$\begin{array}{l}\text { Mass of Organophilic } \\
\text { Clay Solids per Unit } \\
\text { Area of Kaolinite }\left(\mathrm{g} / \mathrm{m}^{2}\right)\end{array}$} & \multicolumn{2}{|c|}{ Initial Distribution for NAPL (\%) } & \multicolumn{3}{|c|}{ Final Distribution for NAPL (\%) } \\
\hline & & & & Kaolinite & $\begin{array}{c}\text { Organophilic } \\
\text { Clay }\end{array}$ & Kaolinite & $\begin{array}{c}\text { Organophilic } \\
\text { Clay }\end{array}$ & $\begin{array}{l}\text { Expelled } \\
\text { NAPL (\%) }\end{array}$ \\
\hline 173.9 & 34.9 & 29 & 0 & 100 & - & 51 & - & 49 \\
\hline 136.1 & 33.2 & 28 & 10400 & 100 & 0 & 27 & 73 & 0 \\
\hline 154.7 & 65.6 & 50 & 0 & 100 & - & 40 & - & 60 \\
\hline 146.4 & 62.9 & 49 & 10400 & 100 & 0 & 14 & 47 & 38 \\
\hline 167.1 & 94.7 & 70 & 0 & 100 & - & 79 & - & 21 \\
\hline 136.1 & 72.2 & 70 & 10400 & 100 & 0 & 47 & 32 & 21 \\
\hline
\end{tabular}


NAPL could not be completely recovered by the hexane extraction procedure, the percentages of NAPL in the kaolinite and organophilic clay were estimated using the ratio of the mass of NAPL in organophilic clay to kaolinite obtained from hexane extraction. The dry weight of organophilic clay was $21 \mathrm{~g}$ in the tests where organophilic clay was used. The adsorption capacity of organophilic clay was found similar in the three tests and averaged $1.2 \mathrm{ml}(0.93 \mathrm{~g})$ of NAPL per $1 \mathrm{~g}$ of organophilic clay solids. The results indicate that organophilic clay reached its capacity independent of the volume and rate of NAPL expelled

Volume of NAPL/ Weight of Soil Solids (ml/g)

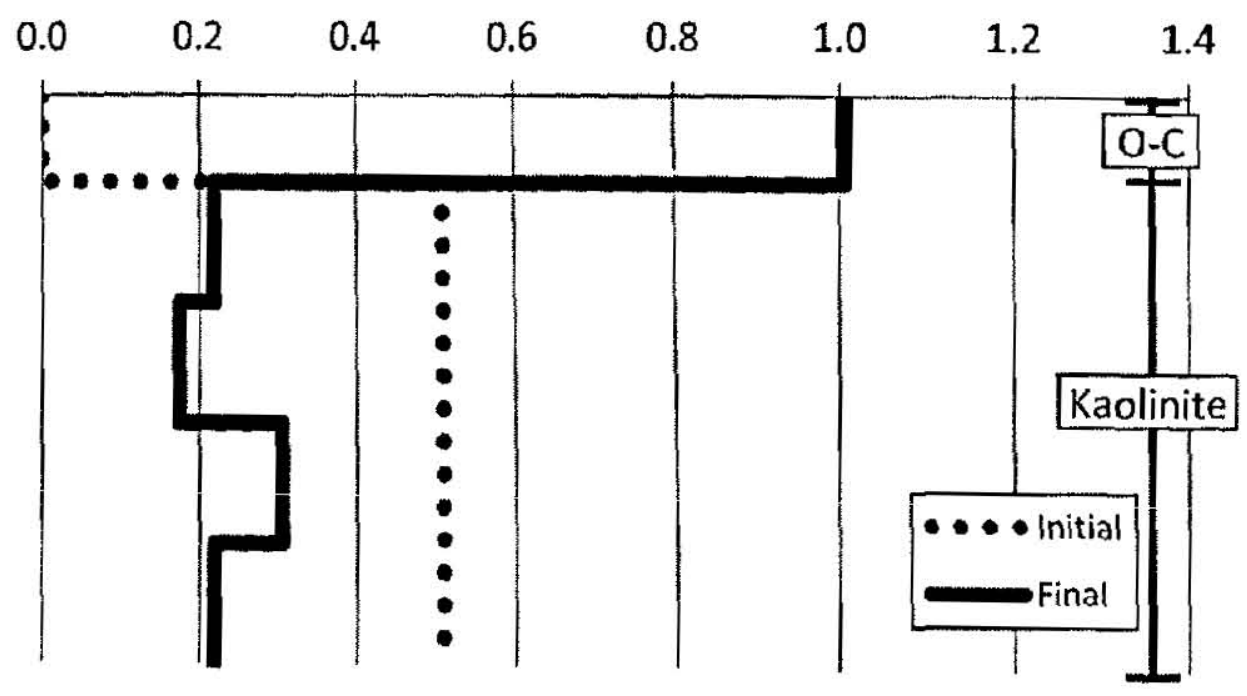

(a)

Volume of Water/ Weight of Soil Solids $(\mathrm{ml} / \mathrm{g})$

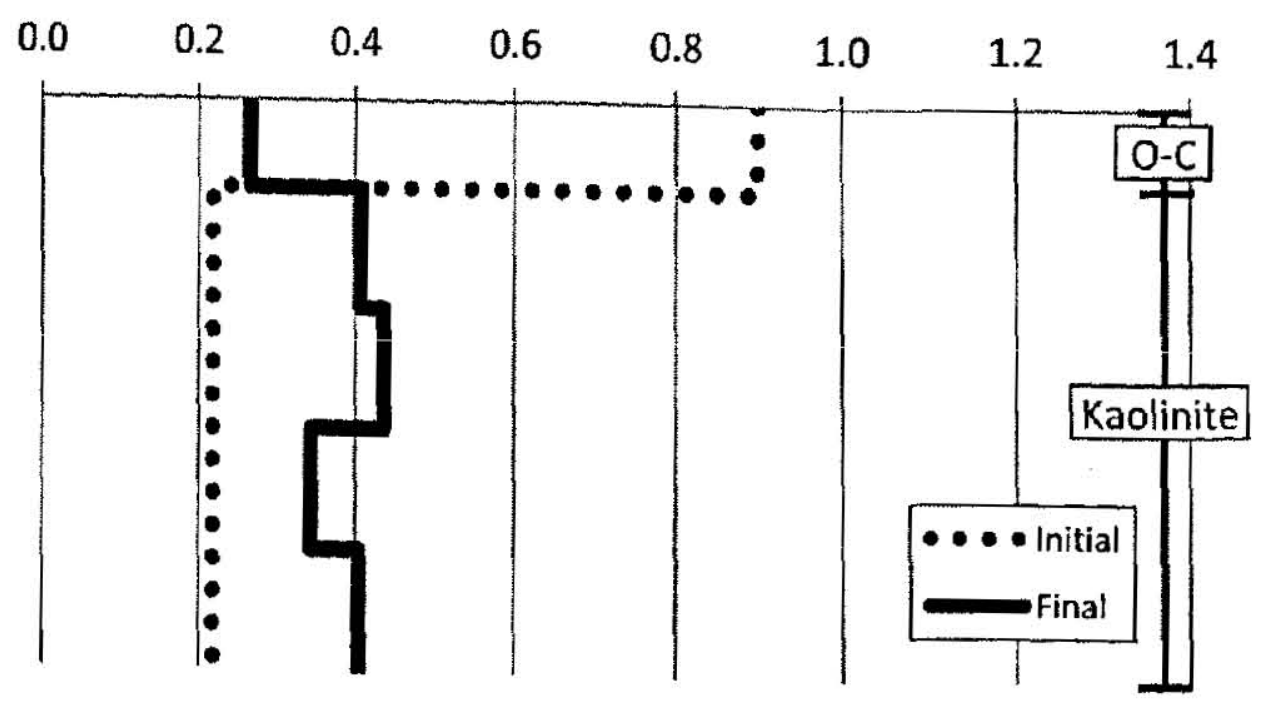

(b)

FIG. 6-(a) NAPL and (b) water distribution along the specimen before the consolidation when the initial NAPL saturation was $70 \%$. 
due to consolidation in these tests. These data provide guidance to estimate the quantity of organophilic clay needed for site-specific applications.

The organophilic clay was observed to adsorb NAPL before no consolidation was initiated. For example, one specimen with a layer of organophilic clay at an initial NAPL saturation of $70 \%$ was left in contact with a layer of organophilic clay for 1 day under undrained conditions, and then dissected to perform moisture content and hexane extraction tests. Figure 6 shows the water and NAPL distribution along the specimen after 1 day. As seen in Fig. $6(b)$, water has moved into the kaolinite and the NAPL in kaolinite was adsorbed into the organophilic clay (Fig. 6(a)). Organophilic clay adsorbed NAPL almost to its full capacity even without any consolidation-induced expulsion of NAPL. The consequence of this interaction is that more NAPL is expelled from sediment at this high initial NAPL saturation because the organophilic clay promotes consolidation, explaining why NAPL is still expelled when organophilic clay was placed on top of the specimen with $70 \%$ NAPL saturation (Table 4).

\section{Conclusion}

The results showed that organophilic clay can be effective at reducing the amount of NAPL that may be displaced from a sediment during cappinginduced consolidation. The tests on specimens with no organophilic clay layer indicated that when the NAPL saturation of the specimen increased, the clay particles formed a less compressible structure, which reduced the amount of expelled NAPL after consolidation. When the amount of organophilic clay used on top of sediment increased, the NAPL displacement reduced. The results imply that if a sufficient amount of organophilic clay is used, NAPL release can be stopped. For the conditions of this study, no NAPL breakthrough was observed when the initial NAPL saturation of kaolinite was $28 \%$ and $10400 \mathrm{~g} / \mathrm{m}^{2}$ of organophilic clay was used. Final NAPL contents of organophilic clay indicated that the adsorption capacity of the organophilic clay was about $1.2 \mathrm{ml}(0.93 \mathrm{~g})$ per $1 \mathrm{~g}$ of organophilic clay. The tests showed that organophilic clay pulled NAPL out of kaolinite even before consolidation, which subsequently can reduce its adsorption capacity during consolidation. These data provide guidance to estimate the quantity of organophilic clay needed for site-specific applications.

\section{References}

[1] Zeman, A. J., "Subaqueous Capping of Very Soft Contaminated Sediments," Can. Geotech. J., Vol. 31, 1994, pp. 570-577.

[2] Azcue, J. M., Zeman, A. J., Mudroch, A., Rosa, F., and Patterson, T., "Assessment of Sediment and Porewater After one Year of Subaqueous 
Capping of Contaminated Sediments in Hamilton Harbour, Canada," Water Sci Tech., Vol. 37, 1998, pp. 323-329.

[3] Moazed, H. and Viraraghavan, T., "Removal of Oil From Water by Bentonite Organoclay," Pract. Period. Hazard. Toxic Radioact. Waste Manage., Vol. 9, 2005, pp. 130-134.

[4] Alther, G. R., "Organically Modified Clay Removes Oil From Water," Waste Manage., Vol. 15, 1995, pp. 623-628.

[5] Paul, D., Zeng, Q., Yu, A., and Lu, G., "The Interlayer Swelling and Molecular Packing in Organoclays," J. Colloid Interface Sci., Vol. 292, 2005, pp. 462-468.

[6] Lo, I. M. C. and Yang, X., "Use of Organoclay as Secondary Containment for Gasoline Storage Tanks," J. Environ. Eng., Vol. 127, 2001, p. 154.

17] Steward, K. K., "Development of Apparatus and Method for Consolidating Very Soft, Contaminated Sediment," M.S. thesis, The University of Texas at Austin, Austin, TX, 2007.

[8] Moretti, L. K., "Evaluation of Capping NAPL-Contaminated Sediment," M.S.Eng. thesis, The University of Texas at Austin, Austin, TX, 2008.

[9] Erten, M. B., Gilbert, R. B., El Mohtar, C. S., and Reible, D. D., "Development of a Laboratory Procedure to Evaluate the Consolidation Potential of Soft Contaminated Sediments," Geotech.Test. J., Vol. 34, 2011, 467-475.

[10] Grim, R. E., Clay Mineralogy, McGraw-Hill, New York, 1968.

[11] Meegoda, N. J., "Compressibility of Contaminated Fine-Grained Soils," Geotech. Test.J., Vol. 17, 1994, pp. 101-112.

[12] Mesri, G. and Olson, R., "Mechanisms Controlling the Permeability of Clays," Clays Clay Miner., Vol. 19, 1971, pp. 151-158.

[13] Palermo, M., Maynord, S., Miller, J., and Reible, D., "Guidance for In-Situ Subaqueous Capping of Contaminated Sediments," EPA 905B96-004, Great Lakes National Program Office, U.S. Environmental Protection Agency, Chicago, IL, 1998.

[14] Erten, M. B., El Mohtar, C. S., Reible, D. D., and Gilbert, R. B., "Consolidation Properties of NAPL Contaminated Sediments," in GeoCongress, March 25-29, 2012, The Geo-Institute of ASCE, Oakland, CA, 2012.

[15] El-Sherbiny, R. M., "Performance of Suction Caisson Anchors in Normally Consolidated Clay," Ph. D. dissertation, Civil, Architectural, and Environmental Engineering, The University of Texas at Austin, 2006.

[16] U.S. Environmental Protection Agency, "Method 3540-C: Soxhlet Extraction," Test Methods for Evaluating Solid Waste, Washington, DC, 1998.

[17] ASTM D2216-10, 2010, "Standard Test Methods for Laboratory Determination of Water (Moisture) Content of Soil and Rock by Mass," Annual Book of ASTM Standards, Vol. 04.08, ASTM International, West Conshohocken, PA.

[18] Lambe, T. W. and Whitman, R. V., Soil Mechanics, John Wiley and Sons, New York, 1969. 